\title{
ANALISIS PENGARUH PEMBERIAN KOMPENSASI NON FINANSIAL TERHADAP KOMITMEN DAN KINERJA GURU
}

\author{
Reni Oktavianti ${ }^{1}$, Soedjarwo ${ }^{2}$, \& Ismet Basuki ${ }^{3}$ \\ ${ }^{1}$ Pascasarjana Manajemen Pendidikan, Universitas Negeri Surabaya, \\ Surabaya, Indonesia \\ E-mail: renioktavianti@unesa.ac.id \\ ${ }^{2}$ Pascasarjana, Universitas Negeri Surabaya, Surabaya, Indonesia \\ E-mail: soedjarwo@unesa.ac.id \\ ${ }^{3}$ Pascasarjana, Universitas Negeri Surabaya, Surabaya, Indonesia \\ E-mail: ismetbasuki@unesa.ac.id
}

\begin{abstract}
Abstrak: Sekolah mempunyai tanggung jawab untuk menyelenggarakan pendidikan berkualitas yang sesuai dengan tujuan nasional pendidikan. Oleh karenanya dibutuhkan tenaga pendidik yang kompeten. Salah satu upaya untuk meningkatkan komitmen dan kinerja guru adalah dengan pemberian kompensasi non finansial. Berdasarkan gambaran di atas maka penelitian ini ingin mengetahui pengaruh kompensasi non finansial terhadap komitmen dan pengaruhnya terhadap kinerja guru. Dalam melihat pengaruh tersebut diuji baik secara langsung maupun tidak langsung melalui variabel antara yaitu variabel komitmen guru dengan kompensasi non finansial dibagi menjadi dua yaitu variable imbalan karier dan imbalan sosial. Penelitian ini merupakan explanatory research, dengan desain penelitian survei. Sedangkan Teknik analisis data yang digunakan untuk menjawab hipotesis dalam penelitian ini adalah menggunakan model partial least square (PLS) pada populasi 126 guru dengan jumlah sampel penelitian 96 guru yang diambil dari populasi. Hasil penelitian menunjukkan bahwa komitmen guru berpengaruh secara signifikan terhadap kinerja guru sebesar t-statistik 2.406, pengaruh pemberian imbalan sosial memiliki pengaruh yang signifikan terhadap komitmen guru dengan nilai t-statistik 3.873 maupun kinerja guru dengan nilai t-statistik 2.860. Sedangkan pemberian imbalan karier hanya berpengaruh secara signifikan terhadap komitmen guru dengan nilai t-statistik sebesar 2.589. Hal tersebut cukup menarik karena perlu dimediasi oleh komitmen guru agar pemberian imbalan karier meiliki pengaruh yang signifikan terhadap kinerja guru. Fenomena ini tentunya menarik untuk dijadikan bahan diskusi. Selain itu penambahan variabel antara lainnya seperti motivasi hendaknya dijadikan bahan pertimbangan untuk penelitian selanjutnya.
\end{abstract}

Kata-kata kunci: imbalan karier; imbalan sosial; komitmen guru; dan kinerja guru.

\section{ANALYSIS OF THE EFFECT OF GIVING NON-FINACIAL COMPENSATION ON TEACHER'S COMMITMENT AND PERFORMANCE}

\begin{abstract}
Schools has the responsibility to organize quality education in accordance with the national objectives of education. Therefore, it takes a competent educators. One effort to increase the commitment and performance of teachers is the provision of non-financial compensation. Based on the description above, this study aimed to determine the effect of non-financial compensation to the commitment and impact on teacher's performance. Looking at these effects that were tested either directly or indirectly through intermediate variable is the variable commitment of teachers to non-financial compensation is divided into two rewards career and social rewards. This research is an explanatory research, with survey research design. Data analysis technique used to review answering hypothetical
\end{abstract}


model research singer using partial least squares (PLS) with a population of 126 teachers Term Research sample 96 teachers Taken Out of a population. Research shows that commitment has a significant influence towards teacher's performance with t-statistic result 2.406, rewarding social influences have a significant effect against the commitment of teachers with $t$-statistic value and costs 3,873 teachers with $t$-statistic value 2,860 . While career rewards has significant effect on teachers' commitment against with t-statistic values of 2.589 . This is quite interesting because it should be mediated by the commitment of teachers so career rewards has particularly significant influence toward teacher's performance. This interesting phenomenon is worth for a discussion. In addition between disposals other variables such as motivation should be a material consideration for further research review.Keywords: Leadership, Islamic boarding school culture, teacher's motivation, quality of education..

Keywords: career rewards, social rewards, teachers' commitment, teachers, performance

\section{PENDAHULUAN}

Mulyasa (2004: 5) mengatakan bahwa guru merupakan komponen paling menentukan, karena di tangan gurulah kurikulum, sumber belajar, sarana prasarana, serta iklim pembelajaran menjadi sesuatu yang berarti bagi kehidupan peserta didik. Oleh karena itu, kualitas dan kinerja guru menjadi hal utama yang dimiliki oleh sebuah lembaga pendidikan untuk mewujudkan pendidikan yang bermutu.

Salah satu aspek penting yang harus diperhatikan sekolah dalam usaha untuk memberikan stimulasi positif terhadap peningkatan komitmen dan kinerja guru yaitu dengan merancang kebijakan sekolah yang terkait dengan ketenagaan. Adapun kebijakan yang diharapkan mampu memberikan stimulasi positif terhadap komitmen dan kinerja guru yaitu melalui kebijakan pemberikan kompensasi. Hal ini senada dengan pendapat Handoko (1996: 156) yang menyatakan bahwa suatu cara meningkatkan prestasi kerja, motivasi dan kepuasan kerja karyawan adalah dengan memberikan kompensasi.

Handoko (1996: 135) menyatakan bahwa kompensasi adalah segala sesuatu yang diterima para karyawan sebagai balas jasa atas kerja mereka dan kompensasi itu sendiri dapat dibagi menjadi dua yaitu: kompensasi finansial dan kompensasi non finansial atau ada yang menyebutnya kompensasi moneter dan kompensasi non moneter. Sedangkan Schuler dan Jackson (1999: 86) membagi kompensasi non finansial menjadi dua bentuk yaitu: imbalan karier dan imbalan sosial. (1) Imbalan karier berupa rasa aman, pengembangan diri, fleksibilitas karier, peluang kenaikan penghasilan dan (2) Imbalan sosial berupa simbol status, pujian dan pengakuan, kenyamanan tugas, dan persahabatan. Kedua bentuk kompensasi non finansial tersebut akan digunakan sebagai variabel dalam penelitian ini.

Glickman (1995:124) menggambarkan ciriciri komitmen guru profesional yaitu: (1) tingginya perhatian terhadap siswa-siswi dengan cara: memberikan bimbingan dan mengadakan komunikasi yang intensif untuk memeroleh infomasi tentang anak didik; (2) banyaknya waktu dan tenaga yang dikeluarkan; (3) bekerja sebanyak-banyaknya untuk orang lain. Terkait dengan tugas tersebut, para guru dibebankan dengan tugas-tugas sebagai yaitu: guru memiliki tugas professional; guru memiliki tugas kemanusiaan; dan guru memiliki tugas kemasyarakatan.

Guru yang memiliki komitmen terhadap tugas setidaknya dari dalam dirinya terpancar beberapa sikap yaitu: (1) tugas sebagai guru merupakan pancaran sikap batin, (2) siap sedia dimanapun, (3) tanggap terhadap perubahan.

Komitmen organisasi terbangun bila tiap individu mengembangkan tiga sikap yang saling berhubungan terhadap organisasi atau profesi seperti: (1) identification, (2) involvement, dan (3) loyalty.

Pugach (2006) menjelaskan lima aspek dari komitmen guru, yaitu: (1) belajar dari berbagai sumber ilmu pengetahuan, (2) menjalankan kurikulum dengan bertanggung jawab, (3) menggantikan batasan-batasan yang dimiliki dengan batasan umum yang lebih beranekaragam, (4) membicarakan kebutuhan pribadi siswa dalam lingkungan kelas dan sekolah, dan (5) memberikan kontribusi secara aktif pada profesinya

Kinerja guru adalah hasil yang dicapai oleh guru dalam melaksanakan tugas mengajar yang bermutu. Kinerja guru adalah perwujudan kerja yang dilakukan oleh guru di sekolah dan masyarakat yang biasa digunakan sebagai dasar penilaian terhadap guru. Kinerja guru dapat dilihat dan diukur berdasarkan spesifikasi atau kriteria kompetensi yang harus dimiliki oleh setiap guru. Sedangkan kompetensi guru seperti yang telah dijelaskan pada bab sebelumnya, berdasarkan UU. RI. No. 14 tahun 2005 tentang guru dan dosen dan PP. No. 74 tahun 2008 tentang guru pasal 3 ayat (2) ada 4 yaitu: (1) kompetensi pedagogik, (2) kompetensi kepribadian, (3) kompetensi sosial, dan (4) kompetensi profesional. Pada artikel ini dilihat bentuk kinerja guru melalui 
kompetensi guru. Kompetensi guru yang digunakan dalam menilai kinerja guru pada penelitian ini adalah kompetensi pedagogik dan kompetensi profesional, karena berdasarkan studi pendahuluan, ditemukan banyak kelemahan pada 2 kompetensi ini.

Berdasarkan gambaran tentang pentingnya pemberian kompensasi non finansial yang berupa imbalan karier dan imbalan sosial, komitmen dan kinerja guru, yang telah dijelaskan di atas, tujuan penelitian ini dilakukan untuk melihat keterkaitan kedua variabel, yaitu imbalan karier dan imbalan sosial tersebut dalam memberikan pengaruh, baik langsung dan tidak langsung terhadap komitmen dan kinerja guru di SMP A. Wahid Hasyim Tebuireng Jombang dan SMP Darul Ulum 1 Unggulan Jombang. Penelitian ini akan menguji tujuh hipotesis, yaitu: (1) kompensasi non finansial yang berupa imbalan karier berpengaruh terhadap komitmen guru, (2) kompensasi non finansial yang berupa imbalan sosial berpegaruh terhadap kinerja guru, (3) kompensasi non finansial yang berupa imbalan karier berpengaruh terhadap kinerja guru melalui komitmen guru, (4) kompensasi non finansial yang berupa imbalan sosial terhadap komitmen guru (5) kompensasi non finansial yang berupa imbalan sosial terhadap kinerja guru (6) kompensasi non finansial yang berupa imbalan sosial yang berpengaruh terhadap kinerja guru melalui komitmen guru, dan (7) komitmen guru berpengaruh terhadap kinerja guru.

\section{METODE PENELITIAN}

Penelitian ini mengungkap secara kuantitatif tentang pengaruh langsung dan tidak langsung kompensasi non finansial terhadap komitmen dan kinerja guru. Secara detail penelitian ini digambarkan sebagai berikut.

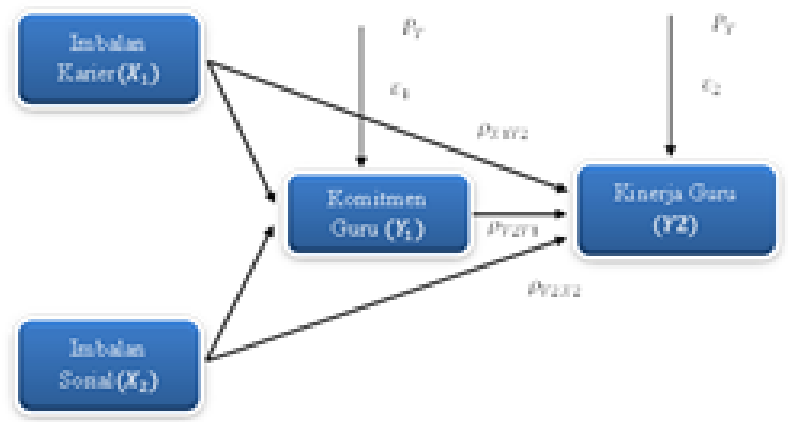

Gambar 1 Desain Penelitian: Pengaruh Antar Variabel

Penelitian ini dilakukan dengan menggunakan metode survei. Penelitian dilakukan pada 126 guru di SMP A. Wahid Hasyim Tebuireng Jombang dan
SMP Darul Ulum 1 Unggulan Jombang. Penelitian ini dilakukan dengan menggunakan empat instrumen penelitian, yaitu: (1) kuesioner imbalan karier yang diukur melalui indikator rasa aman, pengembangan diri, peluang kenaikan penghasilan, dan fleksibilitas karier, (2) kuesioner imbalan sosial yang diukur melalui indikator kenyamanan tugas, persahabatan, pujian dan pengakuan, dan simbol status, (3) kuesioner komitmen guru yang diukur melalui dimensi identification, involvement dan loyalty, dan (4) lembar observasi kinerja guru yang diukur melalui 2 kompetensi yaitu kompetensi pedagogik dan kompetensi profesional. Masing-masing instrumen diukur melalui pengukuran rating scale. Keempat instrumen penelitian sebelum digunakan telah melalui penentuan validitas dan reliabilitas. Penentuan validitas instrumen meliputi penentuan validitas konstruk, validitas isi, validitas muka, validitas butir, dan penentuan reliabilitas. Penentuan validitas konstruk dilakukan dengan merumuskan butir dengan mengacu pada konstruk yang diukur melalui indikator. Penentuan validitas isi instrumen dilakukan dengan menggunakan kisi-kisi yang telah ditetapkan berdasarkan kajian teori. Adapun penentuan validitas muka dilakukan dengan mengonsultasikan instrumen kepada tiga orang ahli dibidangnya masing-masing. Sedang penentuan validitas butir dilakukan dengan menghitung korelasi antar skor butir dengan skor total dan uji indek daya beda, dan uji reliabilitas dilakukan dengan metode Alpha Cronbach untuk instrumen kuesioner imbalan karier, imbalan sosial dan komitmen guru, dan uji beda 2 persepsi pengamat untuk instrumen lembar observasi kinerja guru). Teknik analisis data yang digunakan dalam penelitian ini adalah dengan menggunakan metode Partial Least Square (PLS).

\section{HASIL DAN PEMBAHASAN}

Pengujian hipotesis penelitian ini menggunakan teknik analisis PLS yang dilakukan dengan evaluasi outer model dan inner model. Evaluasi model pengukuran adalah evaluasi hubungan antara konstruk dengan indikatornya. Evaluasi ini melalui dua tahap yaitu evaluasi terhadap convergent validity dan discriminant validity. Convergent validity meliputi (1) individual item relibiality, (2) internal consistency atau construct relibiality, dan (3) average variance extracted $(A V E)$. Sedangkan pemeriksaan terhadap discriminant validity meliputi cross loading dan membandingkan dengan akar $A V E$ dengan korelasi antar konstruk.

Model struktural dari penelitian digambarkan sebagai berikut. 


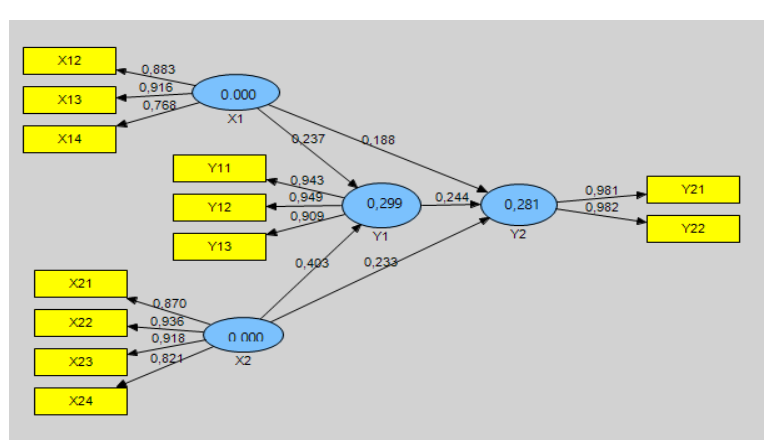

Gambar 2 Model Struktural

Setelah pemeriksaan model pengukuran terpenuhi, maka selanjutnya adalah pemeriksaan terhadap model struktural atau outer model. Pemeriksaan ini meliputi signifikansi (1) $r$-squared value, (2) path coefisient, dan (3) T-statictic. Berdasarkan pada hasil evaluasi kedua model tersebut didapat nilai path coeficient sebagai berikut.

Tabel 1

Nilai Path Coefisient (Means, STDEV, T-Value)

\begin{tabular}{llllll}
\hline & $\begin{array}{c}\text { Original } \\
\text { Sample } \\
(\mathrm{O})\end{array}$ & $\begin{array}{c}\text { Sample } \\
\text { Mean } \\
(\mathrm{M})\end{array}$ & $\begin{array}{c}\text { Standar } \\
\text { Deviation } \\
(\mathrm{STDEV})\end{array}$ & $\begin{array}{c}\text { Standard } \\
\text { Error } \\
(\text { STERR })\end{array}$ & $\begin{array}{c}\mathrm{T} \\
\text { Statistics } \\
(\mid \mathrm{O} / \\
\text { STERR } \mid)\end{array}$ \\
\hline $\mathrm{X} 1$-> Y1 & 0.237 & 0.245 & 0.09 & 0.092 & 2.559 \\
$\mathrm{X} 1$-> Y2 & 0.246 & 0.218 & 0.134 & 0.135 & 1.828 \\
$\mathrm{X} 2$-> Y1 & 0.403 & 0.405 & 0.096 & 0.096 & 4.175 \\
$\mathrm{X} 2$-> Y2 & 0.331 & 0.352 & 0.117 & 0.117 & 2.837 \\
$\mathrm{Y} 1$ - > Y2 & 0.244 & 0.240 & 0.101 & 0.101 & 2.406 \\
\hline
\end{tabular}

Berdasarkan pada tabel di atas maka dapat diketahui bahwa uji hubungan antar konstruk menunjukkan bahwa semua konstruk memiliki nilai t-statistik $>1.96$, yang berarti bahwa setiap variabel memiliki pengaruh signifikan terhadap variabel lainya. Hanya variabel imbalan karier (X1) terhadap kinerja guru (Y2) adalah sebesar 1,828 dengan nilai original sampel bertanda positif, nilai $t$ statistik lebih kecil dari nilai $\mathrm{t}$ tabel dan nilai original sampel bertanda positif yang berarti imbalan karier (X1) berpengaruh positif namun tidak signifikan terhadap kinerja guru (Y2). Sehingga model perlu diperbaiki dengan cara mengeluarkan koefisien jalur X1 ke Y2 dari model yang biasa disebut dengan trimming. Setelah mengevaluasi model struktural pada model pertama,

Model diagram jalur setelah proses trimming sebagai berikut.

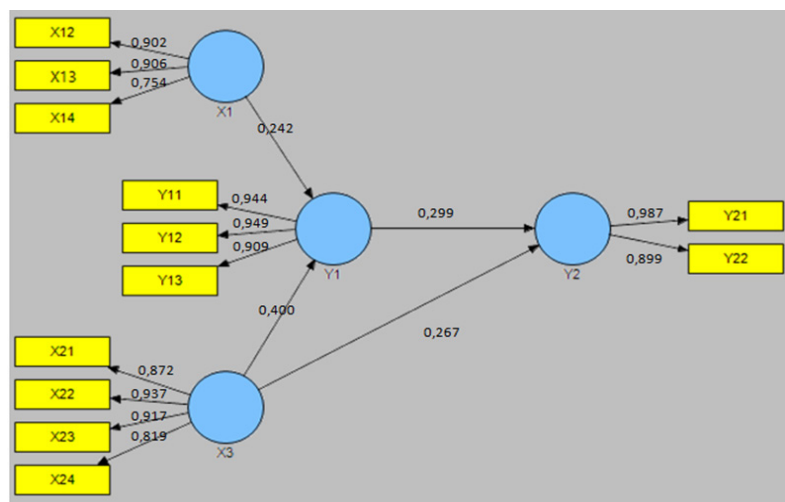

Gambar 3 Model Struktural

Analisis jalur memperhitungkan pengaruh langsung dan tidak langsung. Pengaruh langsung adalah pengaruh eksogen terhadap variabel endogen tanpa melalui variabel eksogen lainnya. Sedangkan pengaruh tidak langsung adalah pengaruh dimana variabel eksogen yang memengaruhi variabel endogen melalui variabel lain yang disebut variabel intervening. Berdasarkan hasil analisis yang telah dilakukan diperoleh pengaruh langsung dan tidak langsung seperti berikut ini.

Tabel 2

Nilai Path Coefisient (Means, STDEV, T-Value)

Pengaruh Langsung dan Tak Langsung

\begin{tabular}{|c|c|c|c|}
\hline Variabel & $\begin{array}{l}\text { Pengaruh } \\
\text { Langsung }\end{array}$ & $\begin{array}{c}\text { Pengaruh } \\
\text { Tidak } \\
\text { Langsung } \\
\text { melalui } \\
\text { Variabel } \\
\text { Komitmen } \\
\text { Guru (Y1) }\end{array}$ & Kesimpulan \\
\hline $\begin{array}{l}\text { Imbalan } \\
\text { Karier (X1) }\end{array}$ & $0.188^{* *}$ & $0.058^{* *}$ & $\begin{array}{l}\text { DE > IE, tapi } \\
\text { DE tidak } \\
\text { signifikan } \\
\text { berarti } \\
\text { pengaruh } \\
\text { tidak } \\
\text { langsung }\end{array}$ \\
\hline $\begin{array}{l}\text { Imbalan } \\
\text { Sosial (X2) }\end{array}$ & $0.233^{* *}$ & $0.098^{* *}$ & $\begin{array}{l}\mathrm{DE}>\mathrm{IE} \\
\text { berarti } \\
\text { pengaruh } \\
\text { langsung }\end{array}$ \\
\hline
\end{tabular}

Keterangan:

** koefisien jalur signifikan

Ns: koefisien jalur tidak signifikan

Berdasarkan pada tabel 2 atas dapat dilihat nilai pengaruh langsung dan tidak langsung antar variabel pada model penelitian ini. Hasil pengujian analisa menunjukkan bahwa hanya imbalan karier (X1) yang tidak berpengaruh langsung terhadap kinerja guru 
(Y2).

Bertolak dari hasil penelitian yang telah dilakukan, imbalan karier berpengaruh terhadap komitmen guru, sehingga hasil penelitian ini menerima hipotesis pertama. Hasil penelitian ini sejalan dengan teori Gibson (1996) yang menyatakan bahwa kompensasi perlu untuk diberikan perusahaan karena kompensasi bisa memengaruhi perilaku individu seperti keluar masuk, absensi, komitmen dari para karyawan. Hal senada pada penelitian Lam dan Zhang (2003: 214-220) yang melakukan penelitian di perusahaan fast food di Hong Kong. Hasil penelitiannya menunjukkan bahwa variabel pelatihan (Training and Development) yang merupakan bagian dari kompensasi non finansial mempunyai pengaruh langsung yang signifikan terhadap komitmen karyawan di ikuti oleh karakteristik pekerjaan dan kompensasi. Selain itu juga diungkapkan oleh Tumaini (2015: 40-42) dalam penelitiannya pada guru dan kepala sekolah di 4 Sekolah Menengah Umum (SMU) di Kota Korogwe yang hasil penelitiannya menunjukkan bahwa guru akan tinggal lebih lama jika ada kepuasan terhadap kriteria promosi/kejelasan karier.

Penelitian lain yang mendukung penelitian ini adalah Kwon dan Blanks (2004: 606-622) yang hasil penelitiannya menunjukkan bahwa salah satu variabel yang memengaruhi peningkatan komitmen adalah dari pemberian kesempatan promosi yang lebih.

Berdasarkan hasil penelitian ini menggambarkan bahwa pemberian imbalan karir tidak berpengaruh secara positif dan signifikan terhadap kinerja guru, sehingga hasil penelitian ini menolak hipotesis kedua yang menyatakan pemberian imbalan karier berpengaruh secara langsung terhadap kinerja guru. Hal ini sesuai hasil penelitian Mochengo, Atambo dan Abuga (2016 : 41-50), yang menunjukkan bahwa strategi pemberian kompensasi non finansial untuk kinerja di sekolah menengah berasal dari motivasi yang diperoleh melalui pengakuan, job enrichment, komunikasi dan terstruktur promosi. Dapat disimpulkan dari hasil penelitian di atas menyatakan pemberian kompensasi non finansial yang berupa promosi (imbalan karier) tidak mampu memberikan pengaruh secara langsung terhadap kinerja melainkan harus dimediasi oleh variabel lain yaitu motivasi.

Penelitian lain yang searah dengan hasil penelitian kali ini adalah penelitian Tausif (2012 : 688) yang melakukan penelitian pada sekolah di Kota Wah Cantt, Pakistan yang menyatakan bahwa ada hubungan positif antara pemberian kompensasi non finansial yang berupa promosi jabatan dan job enrichment yang keduanya juga termasuk dalam imbalan karier terhadap kinerja dengan dimediasi faktor usia guru. Semakin tinggi usia maka semakin besar tingkat kinerjanya. Hal ini jelas bahwa penelitian ini menyatakan imbalan karier tidak mampu memberikan pengaruh secara langsung terhadap kinerja melainkan perlu dimediasi oleh variabel usia. Jika dihubungkan dengan penelitian sekarang, dimana karakteristik responden dengan usia produktif (muda) 30-40 th ada sebanyak 73 guru dengan persentase $57.94 \%$, sehingga jelas pada penelitian ini karakteristik responden didominasi oleh usia muda, sehingga imbalan karier tidak berpengaruh secara langsung terhadap kinerja guru.

Hal senada juga ditunjukkan oleh hasil penelitian Haider,Amir, Hamid, dan Hashim (2016: 341-349) yang menyatakan bahwa pemberian kompensasi non finansial yang berupa fleksibilitas karier tidak mampu memberikan pengaruh secara langsung terhadap peningkatan kinerja karyawan, namun perlu dimediasi oleh variabel lain yaitu kepuasan kerja.

Adapun temuan yang menjadi alasan mengapa tidak ada pengaruh langsung dalam pemberian imbalan karier terhadap kinerja guru. Pertama imbalan karir yang merupakan bagian dari kompensasi non finansial dimana menurut teori motivasi bahwa kompensasi non finansial mampu memenuhi kebutuhan manusia yang lebih tinggi bila kita mengacu pada teori hirarki kebutuhan yang dikemukakan oleh Maslow. Dari teori ini jelas bahwa pemberian kompensasi non finansial dalam hal ini pemberian imbalan karir seperti peluang kenaikan pangkat, kesempatan untuk menempuh jenjang pendidikan yang lebih tinggi pada guru akan mampu memberikan pengaruh dalam aspek motivasi (aktualisasi diri), yang bisa jadi hal ini yang akan meningkatkan kinerja guru tersebut. Dapat diambil kesimpulan bahwa pengaruh langsung imbalan karier terhadap kinerja tidak signifikan dikarenakan ada faktor motivasi yang sebelumnya memediasi. Kedua imbalan karir tidak mampu berpengaruh langsung terhadap kinerja dikarenakan objek penelitian adalah SMP islam swasta yang berbasis pondok, dimana para gurunya sudah terbiasa dengan aturan yang dibuat oleh yayasan. Salah satunya aturan jenjang karier, sehingga para paradigma gurunya sudah tertanam bahwa jenjang karier yang sehat dan transparan hampir tidak mungkin terjadi, karena keputusan terbesar bukan pada kepala sekolah tapi pada ketua yayasan. Selain itu sistem promosi di pondok bersifat tertutup karena menjadi kewenangan mutlak dari pihak yayasan. Mekanisme yang dipakai yayasan untuk menentukan promosi juga tidak tertuang 
dalam aturan khusus sebagaimana dalam sistem kenaikan jabatan yang terjadi pada PNS. Hal tersebut berdampak pada ketidak jelasan kriteria bagi guru untuk bisa masuk pada nominasi karier yang lebih tinggi. Dari alasan di atas maka jelas bahwa imbalan karier hampir mustahil berpengaruh langsung kepada kinerja guru apabila telah tertanam paradigma bahwa jenjang karier tidak ditentukan oleh besarnya prestasi, namun keputusan mutlak ketua yayasan, sehingga perlu faktor lain yang mampu memediasi misalnya: komitmen, kepuasan, usia dan motivasi.

Penelitian ini menerima hipotesis ketiga yang menyatakan pemberian imbalan karier berpengaruh secara terhadap kinerja guru melalui komitmen guru. Hasil penelitian ini sejalan dengan Mondy dan Noe (2002: 374) yang menyatakan adanya ketidakpuasan karyawan terhadap kompensasi yang diterima dapat menimbulkan perilaku yang negatif karyawan terhadap perusahaan dan dampak job withdrawal yang dapat dilihat dari menurunnya komitmen yang pada akhirnya akan menurunkan prestasi kerjanya.

Penelitian lain yang mendukung hasil penelitian ini adalah Nyaga (2015: 240-254) dalam penelitiannya pada sekolah dasar swasta di Kenya, Kimabu yang menyatakan bahwa fleksibilitas pekerjaan, misalnya cuti, yang merupakan bagian dari imbalan karier adalah alat penting karena memberikan karyawan kenyamanan sehingga meningkatkan kinerja dan layanan terhadap masyarakat.

Berangkat dari pernyataan dan hasil penelitian di atas maka disimpulkan perlu adanya variabel lain sebagai bentuk stimulus untuk meningkatkan kinerja guru. Dalam penelitian ini perlu adanya variabel komitmen guru agar kinerja guru meningkat. Namun tidak menutup kemungkinan ada variabel lain yang mampu memberikan stimulus terhadap kinerja guru misalnya: variabel motivasi dan variabel kepuasan.

Pemberian imbalan sosial mampu berpengaruh terhadap komitmen guru. Hasil penelitian tersebut menunjukkan bahwa hipotesis keempat dalam penelitian ini diterima. Hasil penelitian ini sejalan dengan hasil penelitian Waloeyodjati (2010: 90) yang melakukan penelitian mengenai pengaruh imbalan sosial terhadap komitmen karyawan Bank BRI. Dalam penelitian ini salah satu imbalan sosial yang berupa simbol status yaitu rasa bangga karyawan menjadi bagian dari perusahaan, membawa pengaruh positif bagi karyawan untuk tetap menjadi bagian dari organisasi tersebut.

Sulaiman dan Ils (2000: 407-421) juga menggambarkan bahwa komitmen organisasi menyajikan hubungan yang positif dengan usia, jenis kelamin, pendidikan, status pekerjaan, dan variabel kepemilikan organisasi. Dari pernyataan Sulaiman dan Ils (2000) ini dapat diartikan bahwa ada pengaruh imbalan sosial yang berupa simbol status pekerjaan dengan komitmen organisasi. Tumaini (2015: 37-40) yang melakukan penelitian terhadap guru pada 4 sekolah menengah umum di Korogwe yang menyatakan temuan bahwa jika guru bekerja di lingkungan yang tidak kondusif yaitu rekan kerja yang tidak ramah maka mereka bisa mudah berhenti dari profesi guru dan mencari pekerjaan lain di mana mereka dapat bekerja. Hal ini menggambarkan bahwa variabel imbalan sosial yang berupa persahabatan [rekan kerja yang ramah] memiliki pengaruh yang positif terhadap komitmen kerja.

Berangkat dari beberapa pernyataan di atas, maka hasil penelitian ini dapat disimpulkan bahwa telah sesuai dengan pernyataan Ranupandojo dan Husnan (2000: 140) yang menyatakan bahwa mempunyai rekan kerja yang kompak merupakan salah satu kebutuhan sosial dari karyawan yang akan berpengaruh terhadap komitmen kerjanya.

Hasil penelitian ini menggambarkan pemberian imbalan sosial berpengaruh terhadap kinerja guru. Hal ini menunjukkan bahwa menerima hipotesis kelima yang menyatakan imbalan sosial berpengaruh terhadap kinerja guru. Hasil penelitian ini sejalan dengan penelitian Sabina, Okibo, Nyang'au dan Ondima (2015: 62-69) yang menyatakan bahwa pemberian kompensasi non finansial yag berupa imbalan sosial dalam hal ini adalah lingkungan kerja yang nyaman mampu berpengaruh secara signifikan terhadap kepuasan kerja yang akhirnya melahirkan kinerja. Selain itu hasil penelitian ini sejalan dengan Tumaini (2015: 37-40) yang melakukan penelitian terhadap guru pada 4 sekolah menengah umum di Korogwe yang menyatakan bahwa ada guru meningkatkan kinerja pekerjaan mereka dan tinggal lebih lama jika ada ketersediaan fasilitas yang memadai. Jelas bahwa ketersediaan fasilitas yang merupakan salah satu indikator dari imbalan sosial dapat berpengaruh terhadap kinerja guru.

Penelitian ini juga menerima hipotesis keenam yang menyatakan imbalan sosial berpengaruh terhadap kinerja guru melalui komitmen guru. Hasil temuan dari penelitian ini juga didukung oleh Sulaiman dan Ils (2000: 407-421) yang menggambarkan hubungan yang positif antara usia, jenis kelamin, pendidikan, status pekerjaan, dan 'variabel kepemilikan terhadap kinerja organisasi baik secara langsung maupun tidak langsung melalui komitmen organisasi. Hal senada juga diungkapkan oleh Tumaini (2015: 37-40) yang 
melakukan penelitian terhadap guru pada 4 sekolah menengah umum di Korogwe yang menyatakan temuan bahwa ada guru meningkatkan kinerja pekerjaan mereka dan tinggal lebih lama jika ada ketersediaan fasilitas yang memadahi. Jelas bahwa ketersediaan fasilitas yang merupakan salah satu indikator dari imbalan sosial dapat berpengaruh terhadap kinerja guru.

Sedang berdasarkan pada penelitian yang telah dilakukan menunjukkan menerima hipotesis ketujuh yaitu komitmen guru berpengaruh terhadap kinerja guru. Hasil penelitian ini sejalan dengan hasil penelitian Rashid, Sambasivan, dan Johari (2003: 708729) melakukan penelitian terhadap perusahaan yang terdaftar di bursa efek Kuala Lumpur, hasil penelitian menunjukkan bahwa karyawan bersama-sama budaya organisasi mempunyai pengaruh langsung terhadap kinerja perusahaan. Walaupun terdapat variabel budaya organisasi, dalam penelitian tersebut didapatkan hasil empiris bahwa komitmen karyawan mempunyai pengaruh langsung yang positif secara parsial (tanpa melibatkan budaya organisasi) terhadap kinerja karyawan. Pengaruh positif tersebut diperkuat dengan penjelasan peneliti bahwa sebagian besar karyawan di Malaysia mempunyai komitmen yang tinggi untuk bekerja di satu perusahaan, sehingga tingkat perputaran karyawan menjadi rendah. Hal tersebut yang menghasilkan kinerja perusahaan menjadi baik karena tingkat perputaran karyawan (employee turnover) yang rendah.

Sedangkan gambaran imbalan karier, imbalan sosial, komiten guru dan kinerja guru diSMP A. Wahid Hasyim Tebuireng Jombang dan SMP Darul Ulum 1 Unggulan Jombang adalah bahwa pemberian imbalan karir di sekolah tersebut belum begitu baik, hal ini tergambar dari hasil penelitian yang menggambarkan tidak adanya pengaruh langsung imbalan karier terhadap kinerja guru. Sistem kedua sekolah yang menjadi objek penelitian merupakan 2 sekolah swasta dalam naungan yayasan pondok pesantren yang mana sistem promosi karier di pondok bersifat tertutup karena promosi menjadi kewenangan mutlak dari pihak yayasan. Mekanisme yang dipakai yayasan untuk menentukan promosi juga tidak tertuang dalam aturan khusus sebagaimana dalam sistem kenaikan jabatan yang terjadi pada PNS. Hal tersebut berdampak pada ketidakjelasan bagi guru untuk bisa masuk pada nominasi karier yang lebih tinggi. Dari alasan di atas maka jelas pemberian imbalan karier pada kedua sekolah ini masih perlu untuk diperhatikan lagi oleh pihak manajemen dan yayasan. Namun dalam pengaruhnya secara tidak langsung yaitu melalui variabel komitmen, motivasi, usia, dan kepuasan pemberian imbalan karier ini mampu memberikan pengaruh terhadap kinerja guru.

Sedangkan dalam pemberian imbalan sosial di sekolah tersebut, telah menunjukkan hasil yang baik Hal ini menunjukkan adanya lingkungan kerja yang baik di SMP A. Wahid Hayim Tebuireng Jombang dan SMP Darul Ulum 1 Unggulan Jombang, fasilitas guru yang memadahi, hubungan persahabatan antar guru yang kuat dalam SMP A. Wahid Hasyim Tebuireng Jombang dan SMP Darul Ulum 1 Unggulan Jombang. Hasil penelitian tersebut tentu bisa jadi dikarenakan kedua sekolah tersebut yang berada dalam naungan pondok pesantren yang berdasarkan hasil penelitian yang dilakukan oleh Mubarok (2016: 1-11) terkait peran pondok pesantren Miftahul Huda dalam pembinaan moral di lingkungan masyarakat Kelurahan Gading Kasri Kota Malang menunjukkan bahwa bagi masyarakat Kelurahan Gading Kasri, pondok pesantren Miftahul Huda lebih mengajarakkan nilai-nilai moral agama bagi masyarakat Desa Gading Kasri. Karena Pondok Pesantren sangat identik dengan pendidikan agama terutama agama Islam. Untuk nilai-nilai moral yang diajarkan Pondok Pesantren seperti mengajarkan tentang beribadah kepada Allah SWT, saling menghormati antar sesama, dan tidak melakukan perbuatan buruk yang merugikan orang lain. Hal ini sesuai dengan pendapat Kahfi (2003:39), menyatakan bahwa pondok pesantren sangat berperan dalam lingkungan masyarakat, dengan adanya pondok pesantren, maka masyarakat akan memiliki batasan dalam bertindak dan berpikir. Pondok pesantren dapat memberikan nilai moral terhadap masyarakat karena pondok pesantren memiliki fungsi sebagai sumber ilmu sosial dan ilmu akhlak bagi para santri-santri atau orang-orang yang berada di lingkungannya Berdasarkan hasil penelitian yang dilakukan oleh peneliti selain nilai moral keagamaan yang diajarkan Pondok Pesantren Miftahul Huda juga mengajarkan nilai moral sosial.

Sedangkan dalam hal komitmen guru, hasil penelitian menunjukkan bahwa komitmen guru di sekolah tersebut cenderung baik. Hal ini selain terlihat dari hasil penelitian secara empiris, tapi juga terlihat dari data karateristik guru yang menunjukkan bahwa rata-rata masa kerja di kedua sekolah tersebut adalah di atas 10 tahun. Sedangkan dalam hal kinerja, meskipun hasil analisis deskriptif menunjukkan kinerja guru yang baik, namun demikian dari hasil instrumen PKG masih banyak ditemukan guru yang belum menggunakan pembelajaran berbasis teknologi dalam proses pembelajaran. Selain itu masih banyak 
pula guru yang belum mampu menjadi pelopor pembaharuan di lungkungannya dan aktif dalam organisasi kemasyarakatan.

\section{PENUTUP}

\section{Kesimpulan}

Berdasarkan pada hasil penelitian yang telah dilakukan, dapat disimpulkan bahwa imbalan karier memiliki pengaruh terhadap komitmen sebesar $24,2 \%$ sedangkan tidak berpengaruh terhadap kinerja secara langsung. Namun pengaruh imbalan karier secara tidak langsung terhadap kinerja guru melalui komitmen guru sebesar 5.8\%. Pengaruh pemberian imblan sosial terhadap komitmen guru berpengaruh positif sebesar $40 \%$, sedangkan pengaruhnya terhadap kinerja guru sebesar $26.7 \%$. Selain pengaruh langsung terhadap kinerja imbalan sosial juga berpengaruh secara tidak langsung terhadap kinerja guru melalui komitmen guru sebesar 9.8\%. Pengaruh komitmen guru terhadap kinerja guru berkontribusi sebesar $29.9 \%$.

Implikasi penelitian berdasarkan hasil analisis data tersebut, dapat disimpulkan bahwa sekolah atau yayasan perlunya lebih memperhatikan aspek imbalan karier guru dalam bentuk kejelasan jenjang karier, kejelasan kesempatan dalam menempati jabatan tertentu, maupun kejelasan dalam membuat aturan peluang guru dalam memperoleh kenaikan gaji agar mampu meningkatkan komitmen guru yang nantinya akan meningkatkan kinerja guru. Selain itu jika dilihat dari hasil penelitian pemberian imbalan sosial mampu menyumbang kontribusi pengaruh terhadap komitmen para guru sebesar $40 \%$, sehingga kondisi sosial dalam lingkungan sekolah sangat perlu diperhatikan agar mampu memberikan stimulus positif terhadap komitmen dan kinerja guru sehingga sekolah mampu memberikan Sehingga sekolah mampu memberikan layanan prima (service excellent) bagi peserta didik.

Hal riil yang perlu dilakukan sekolah misalnya: perlu adanya kebijakan tegas untuk sebuah lelang jabatan. Hal ini ditujukan agar ada persaingan dan motivasi yang lebih oleh guru untuk menempati jabatan tertentu dan dipastikan penilaian tertinggi pada faktor kinerja bukan faktor like or dislike yang biasa terjadi di sekolah yang dalam naungan yayasan.

\section{DAFTAR PUSTAKA}

Akdon, Sahlan. (2005). Aplikasi statistika dan metode penelitian untuk administrasi dan manajemen. Bandung: Dewa Ruchi.

Arikunto, Suharsimi. (1998). Prosedur penelitian suatu pendekatan praktek. Jakarta: PT. Rineka Cipta.

Bernardin, John. H., \& Joice E, A. Russel. (1995). Human Resource Management: an Experiental Approach. New York: McGraw-Hill Inc.

Cherrington, David J. (1994). Organization Behaviour; the Management of Individual and Organization Performance. 2nd Edition. Massachussetts: Allyn \& Bacon Inc.

Gibson, James L., John M, Ivancevich., \& James H, Donnelly Jr. (1996). Organizations. (Djarkasih, penerjemah). Organisasi; Perilaku, Struktur, Konsep. Edisi 5, Jakarta: Penerbit Erlangga.

Glickman, D. Carl. (1995) Supervision of instruction. Boston: Allyn and Bacon Inc.

Ghozali, Imam., \& Fuad. (2015). Partial Least Squeres, Konsep, Teknik dan Aplikasi Menggunakan Program Smart Pls 3.0 untuk Penelitian Empiris. Semarang: Universitas Diponegoro.

Haider, Maqsood., Alamazep, Aamir., Abu-Bakr, A, Hamid., \& Muhammad, Hashim. (2016). A literature analysis on the importance of non financial rewards for employees' job satisfaction. Abasyn Journal of social sciences. 8(2), 341-354.

Handoko, T. Hani. (1996). Manajemen personalia dan sumber daya manusia. Yogyakarta: BPFE.

Handoko, T. Hani. (2000). Manajemen Personalia dan Sumber Daya Manusia. Edisi Ii, Cetakan Keempat Belas. Yogyakarta: Penerbit BPFE.

Hasibuan, Malayu S. P. (2008). Manajemen Sumber Daya Manusia. Jakarta: PT. Bumi Aksara.

Kelly, C, Paul., Carmen, Tejeda., Delgado., \& Jhon, R, Slate. (2010). Finacial and non financial insentives on teacher recruitment and retention: teachers perspective. Open stax-CNX and licensed under the creative common attribution license 3.0, $1(1), 1-10$.

Kwon,G,Whan., \& Dyole, W, Blank. (2004). Factors related to the organizational and professional commitment of internal auditors. Managerial auditing journal, 19(5), 606-622.

Lam, Terry., \& H.Q, Zhang. (2003). Job satisfaction and organizational commitment in the Hong Kong 
fast food industry. International journal of contemporary hospitality management, 15(4), 214-220.

Retrieved from http://www.emeraldinsight. com/researchregister.

Luthans, Fred. (1992). Organizational behaviour, 6th Edition. Singapore: McGraw-Hill Inc.

Mangkunegara, A. Prabu. (2002). Manajemen sumber daya manusia. Bandung: PT. Remaja Rosda Karya.

Mangkuprawira, Sjafri. (2011). Manajemen sumber daya manusia stratejik. Bogor: Ghalia Indonesia.

Mathis, Robert L., \& John H, Jackson. (2004). Human resource management, 10th edition, (Diana Angelica, penerjemah). Manajemen sumber daya manusia. Edisi 10, Jakarta: Salemba Empat.

Mockengo, N, Sylvester., Wallace, Atambo., \& Mogwambo, V, Abuga. (2016). Impact of non financial reward strategies on teachers' performance: a studay of secondary schools in Nyamira County, Kenya. European journal of business and management, 8(9), 41-50.

Mondy, Wayne R., Robert M. Noe., \& Shane R, Premeaux. (2002). Human resources management, 8 th Edition. New Jersey: Prentice Hall.

Mulyasa, E. (2009). Menjadi guru profesional. Bandung: Remaja Rosdakarya.

Nyaga,W,Josephine. (2015). Non financial reward and employee retention in private primary school in Kenya (Kiambu Country). International journal of management and commerce innovations ISSN 2348-7585, 3(1), 240-254.

Pugach, M. C. (2006). Because teaching matters. USA: Willey/Jossey-Bass Education.

Ranupandojo, Heidjrachman, \& Suad Husnan. (2000). Manajemen Personalia. Yogyakarta: BPFE-UGM.

Rashid, M.Z.A., Murali, Sambasivan., \& Juliana, Johari. (2002). The influence of corporate culture and organisational commitment on performance. Journal of management development. 22 (8): 708-728.
Riduwan. (2012). Skala pengukuran variabel-variabel penelitian. Jawa Barat: IKAPI.

Robbins, Stephen P. (2001). Organizational behaviour: concepts, controversies, aplications. (Hadyana dan Benyamin M, penerjemah). Perilaku organisasi. Edisi 8. Jakarta: PT. Prenhallindo.

Sabina,L,Asiago., et.al (2015). Effect of non financial incentives on job satisfaction of teachers in public secondary schools-survey of Kisii Sub County. Journal of Education and practice, 6(13), 62-70.

Schuler, Randall S., \& Susan E, Jackson. (1999). Human Resource Management. (Abdul Rosyid dan Peter Remy Yosy Pasla, penerjemah). Manajemen sumber daya Manusia. Edisi 6. Jakarta: Penerbit Erlangga.

Sugiyono. (2014). Statistika untuk Penelitian. Bandung: Alfabeta.

Sugiyono. (2011). Metode Penelitian Kuantitatif, Kualitatif Dan RED. Bandung: Alfabeta.

Suliman, Abubakar., \& Paul Iles. (1998). Is continuance commitment beneficial to organizations? Commitment-performance relationship: a new look. journal of managerial psychology. 15 (5): 407-426.

Tausif, Muhammad. (2015). Influence of non financial rewards on job satisfaction: a case study of educational sector of Pakistan. Asians journal of management research. 2(2): 688-696.

Tumaini, Mary. (2015). The contribution of non-monitary incentives to teachers' retention in public secondary schools in Korogwe Urban(Doctoral dissertation). Planning and policy studies of the open University, Tanzania.

Usman, Fauzi. (2014). Pengaruh kompensasi terhadap kinerja karyawan PT. Trakindo Utama Samarinda. Ejournal ilmu administrasi bisnis. 2 (3): 172-185.

Waloeyodjati, Kentok. (2010). Pengaruh Kompensasi Non Finansial Terhadap Komitmen Dan Kinerja Karyawan (Tesis yang tidak dipublikasi), Universitas Brawijaya, Malang. 
60 PERSPEKTIF Ilmu Pendidikan - Vol. 33 No.1 April 2019 